\title{
Diffuse Large B-Cell Lymphoma of the Frontal Sinus Presenting as a Pott Puffy Tumor: Case Report
}

\author{
Nickalus R. Khan ${ }^{1}$ Goran Lakičević ${ }^{2}$ Thomas R. Callihan ${ }^{3}$ George Burruss ${ }^{4}$ Kenan Arnautović 1,5
}

${ }^{1}$ Department of Neurosurgery, University of Tennessee Health Science Center, Memphis, Tennessee, United States

2 Department of Neurosurgery, University Hospital Mostar, Bosnia and Herzegovina

3 Pathology Group of the Midsouth, Memphis, Tennessee, United States

${ }^{4}$ Department of Plastic Surgery, University of Tennessee Health Science Center, Memphis, Tennessee, United States

${ }^{5}$ Semmes-Murphey Neurologic and Spine Institute, Memphis,

Tennessee, United States

J Neurol Surg Rep 2015;76:e23-e27.
Address for correspondence Kenan Arnautović, MD, PhD, SemmesMurphey Neurologic and Spine Institute, 6325 Humphreys Blvd., Memphis, TN 38120, United States (e-mail: kenanarnaut@yahoo.com).

\begin{abstract}
Keywords

- diffuse large B-cell lymphoma

- frontal sinus

- case report

- Pott puffy tumor
\end{abstract}

Objective Sinonasal non-Hodgkin lymphoma (NHL) is a very rare condition. NHL located specifically in the frontal sinus is even rarer with only 14 cases in the literature reported to date. A unique case of diffuse large B-cell lymphoma of the frontal sinus that presented first and was treated as suspected Pott puffy tumor is presented along with a review of the literature.

Case Report A 69-year-old white man with a history of sinusitis and two recent endoscopic sinus surgeries presented with enlargement of his right forehead. Computed tomography and magnetic resonance images revealed a dense opacification of the frontal sinus bilaterally, thickening and enhancement of the dura mater behind the right frontal sinus, and local osteomyelitis-like lytic bone changes. A bifrontal craniotomy was performed. Radical exoneration of the frontal sinus, copious antibiotic-impregnated irrigation after culture swabs, and resection of presumed granulation tissue was performed. Culture swabs remained negative, but histopathology revealed diffuse large B-cell lymphoma. Subsequent chemotherapy was administered.

Conclusion Sinonasal NHL is very rare but can occur in the frontal sinus and may present as a suspected Pott puffy tumor. A high clinical suspicion is necessary for early diagnosis and treatment.

\section{Introduction}

An estimated 79,030 men and women will be diagnosed with lymphoma in the United States in 2014. Non-Hodgkin lymphoma (NHL) encompasses most of these diagnoses $(69,740) .^{1}$ The incidence of sinonasal (nasal cavity and paranasal sinuses) NHL is estimated to be between $0.2 \%$ and $2 \%$ of all NHLs in the Western Hemisphere. ${ }^{2,3}$ A large study from 1987 to 1996 in Nottingham, United Kingdom, found 24 patients of 1,457 (1.63\%) with sinonasal NHL, supporting this claim. Based on these estimates, we can expect between 140 and 1,400 cases of sinonasal NHL in the United States this year. Most sinonasal NHLs are of the large B-cell variety and located within the nasal cavity and maxillary sinus. Frontal received

April 22, 2014

accepted after revision

July 18, 2014

published online

January 16, 2015
DOI http://dx.doi.org/

10.1055/s-0034-1543996. ISSN 2193-6366.
@ 2015 Georg Thieme Verlag KG
Stuttgart · New York

License terms

(®) $\Theta \circledast$ 
sinus NHL is an extremely rare condition. An extensive review of the English-language literature revealed only eight case reports ${ }^{4-11}$ and six cases in case series ${ }^{12-17}$ of primary frontal sinus NHL for a total of 14 cases before this report.

Sinonasal lymphoma can present with a variety of nonspecific symptoms often leading to a late diagnosis and worsened prognosis. We share our experience with a unique case of a 69-year-old white man with frontal sinus NHL who was initially referred for treatment of a Pott puffy tumor.

\section{Case Report}

A 69-year-old white man presented with a chief complaint of "enlargement of his right forehead" and was referred by his primary care physician for the evaluation of a possible Pott puffy tumor. The referring doctor's working diagnosis of Pott puffy tumor was indeed supported by the patient's chief complaint of enlargement of his right forehead, associated headaches, dizziness, eye tenderness, nasal congestion with thick discharge as well as two endoscopic sinus surgeries for chronic sinusitis 2 months prior to this visit. His past medical history was significant for mild asthma, nephrolithiasis, and polymyositis. He had methotrexate therapy for his polymyositis 3 years ago for a total of 3 months. He had a surgical history significant for a cholecystectomy and a hernia repair. Laboratory evaluation, including a complete blood count and metabolic profile, were within normal limits.

A thorough physical examination was performed that revealed a $3 \times 3-\mathrm{cm}$ hard, immobile, and nontender mass on his right forehead. A funduscopic examination was within normal limits. Cranial nerves II to XII were found to be intact. No motor or sensory deficits were observed. There was no lymphadenopathy. Computed tomography (CT) and magnetic resonance image (MRI) scans of his head were performed that revealed dense opacification of the frontal sinus bilaterally with thickening of the dura mater behind the right frontal sinus and osteomyelitis-like lytic bone changes (-Fig. 1). These clinical and radiologic findings further supported the working diagnosis of Pott puffy tumor.

The patient was advised to undergo surgery at this point, and a bifrontal craniotomy was performed by the senior author (K.A.). Radical exoneration of the frontal sinus, copious antibiotic-impregnated irrigation after culture swabs, and resection of presumed granulation tissue was performed, and this tissue was sent for histologic analysis (-Fig. 2). Iliac autograft was used to obliterate frontal sinus. The patient was neurologically intact postoperatively.

\section{Histopathology}

Both intra- and extracranial specimens were evaluated with the latter including frontal sinus contents. The findings in both specimens were similar with an infiltrate of large atypical lymphocytes associated with necrosis, fragments of nonviable bone, variable sclerosis, and admixed small lymphocytes (-Fig. 3A, B). Immunostains performed on paraffin sections showed large atypical lymphoid cells expressing CD20 indicative of B-cell lineage (-Fig. 4) and were also positive for CD30, CD43, and bcl-6. There was no expression of
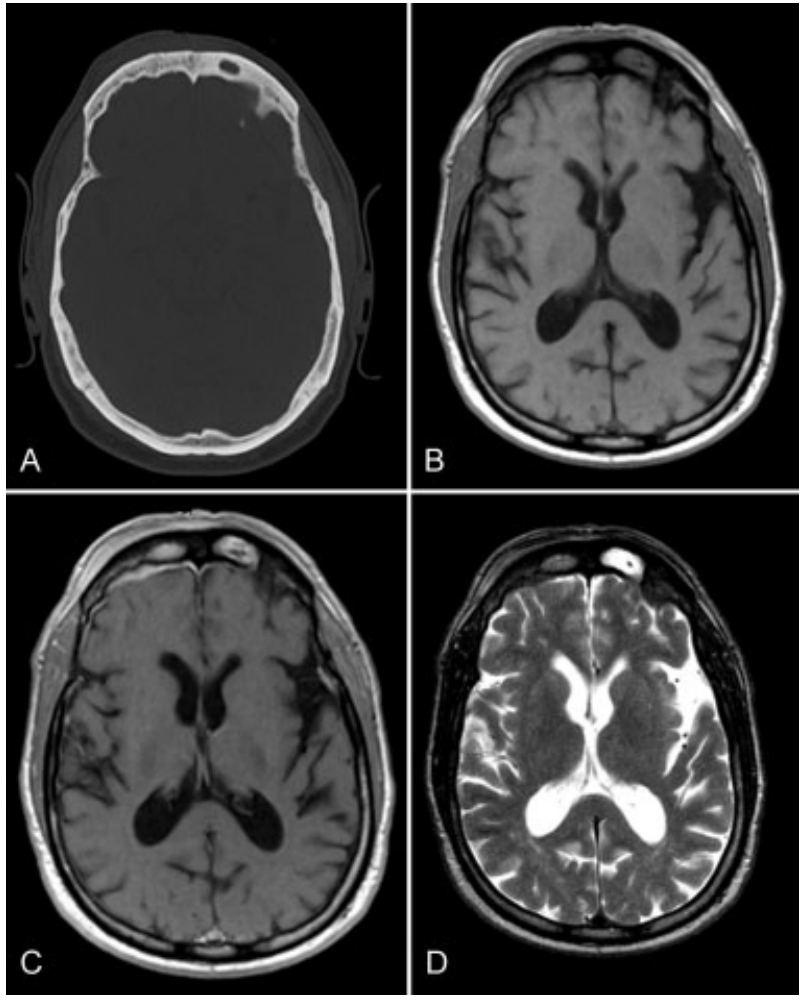

Fig. 1 (A) Preoperative computed tomography scan of the head. (B) Axial T1 noncontrast magnetic resonance imaging (MRI). (C) Axial T1 contrast-enhanced MRI. (D) Axial T2 weighted MRI demonstrating right forehead swelling, frontal sinus opacification, brisk enhancement, and thickening of the dura behind the right frontal sinus and osteomyelitis-like changes.

CD3, CD10, CD15, bcl-2, or MUM-1. The admixed small lymphocytes were nonneoplastic and of T-cell lineage. A diagnosis using the Hans algorithm was made of a large Bcell lymphoma of the germinal center type. ${ }^{18}$ Although there was no rearrangement of the immunoglobulin heavy chain gene, a clonal immunoglobulin kappa light chain gene rearrangement was identified.

\section{Follow-Up}

The patient's oncologist placed him on a chemotherapy regimen of Adriamycin, Cytoxan, Rituxan, and vincristine for a total of 5 months. We continued to monitor him clinically with follow-up CT and MRI scans. His repeat imaging studies have shown him to be radiographically disease free at the time of this report (3 years postdiagnosis). He returned to work within 1 month of his surgery.

\section{Discussion}

Diffuse large B-cell lymphoma is extremely rare. With only eight case reports and six cases within case series in the literature (-Table 1), our experience as a profession with this disease at this location is limited. Of the 14 cases with identifiable demographics in the literature on this topic (including our own), there were 7 men and 2 women with an average age of 60 years. Interestingly, the literature shows the incidence of sinonasal NHL in Asian countries 

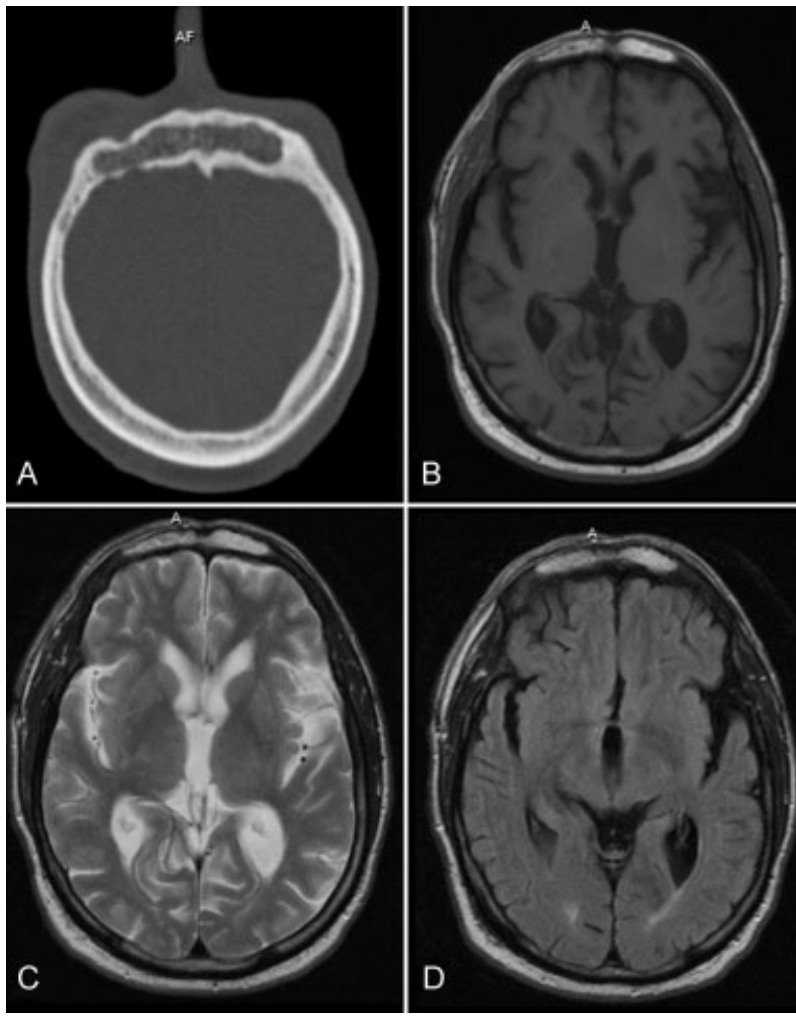

Fig. 2 (A) Postoperative computed tomography scan of the head. (B) Axial T1 non-contrast-enhanced magnetic resonance imaging (MRI). (C) Axial T2 MRI. (D) Axial fluid-attenuated inversion recovery MRI showing postoperative tumor-free changes from a bifrontal craniotomy and radical exenteration of the frontal sinus.

is higher than in the Western Hemisphere. ${ }^{19}$ The subtypes of NHL in Asian countries are more commonly $\mathrm{T}$ cell predominant in contrast to Western countries showing a B-cell predilection. ${ }^{5,12,19-21}$

Pott puffy tumor, first described by Sir Percival Pott in $1760,{ }^{22}$ is a rare clinical entity characterized by a subperiosteal abscess associated with osteomyelitis of the frontal bone. This infection can develop either by direct or hematologic spread. Pott puffy tumor has been associated with cortical vein thrombosis, epidural abscess, subdural empyema, and brain abscesses. This type of chronic osteomyelitis of the frontal bone may be easily confused with acute subperiosteal abscess of the frontal bone often seen as a complication of frontal sinusitis or trauma.

The current paradigm in the diagnosis of diffuse large Bcell lymphoma is based on histologic evaluation and immunochemical staining alone (e.g., CD19, CD20, CD22, CD79a). However, there are several tests before a biopsy that can assist the clinician in differentiating this disease process from infectious processes such as Pott puffy tumor. Elevated leukocyte counts with a leftward shift, elevated erythrocyte sedimentation rate, and elevated C-reactive protein can certainly make the differential diagnosis more indicative of infectious processes. A history of recurrent sinusitis (the most common cause of Pott puffy tumor) or an identified source of hematogenous spread can also point toward infectious processes. A complete history and physical examination
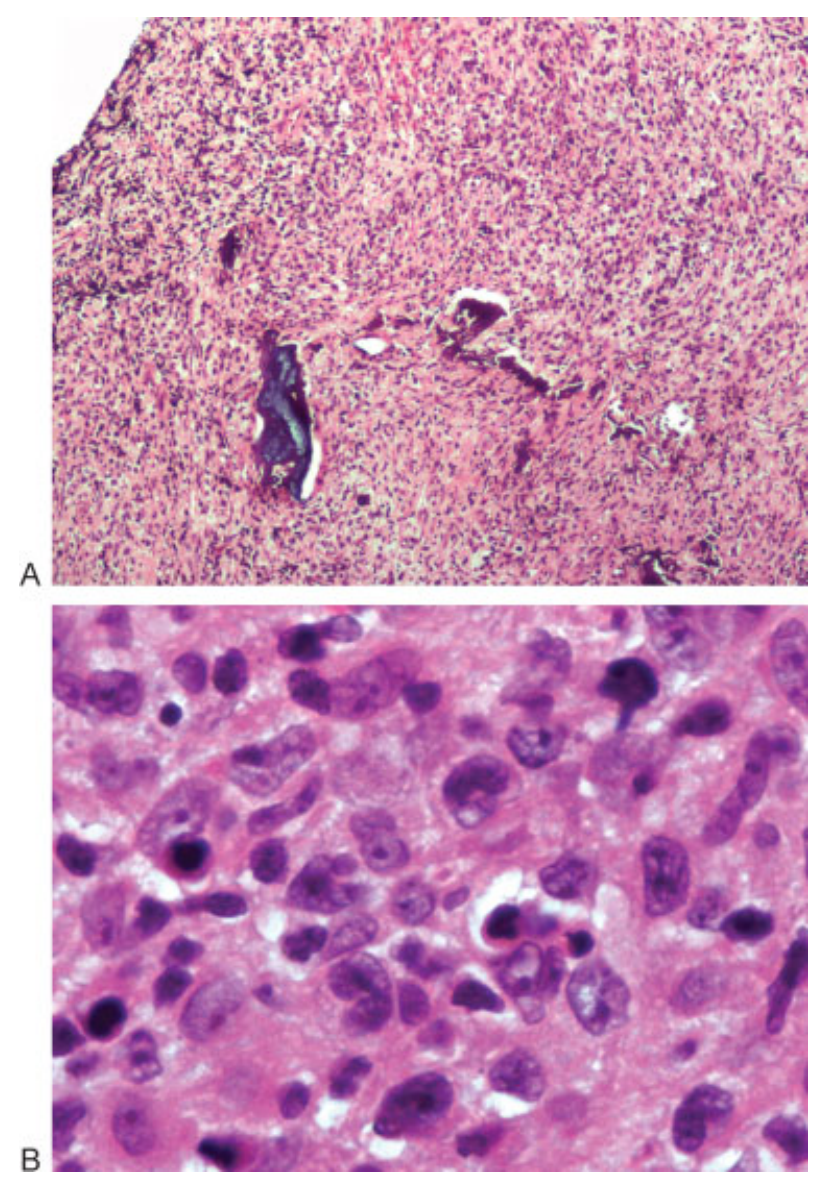

Fig. 3 (A) Diffuse destructive infiltrate with desmoplastic reaction and fragments of bone (hematoxylin and eosin [H\&E], $\times 100$ ). (B) Large atypical lymphocytes with irregular nuclear membranes and prominent nucleoli $(H \& E, \times 1,000)$.

coupled with the laboratory testing just cited can give the physician valuable information that can be used in decision making prior to invasive biopsy.

Throughout the literature, treatment paradigms for diffuse large B-cell lymphoma of the frontal sinus have varied widely including surgery, chemotherapy, stem cell transplants, and

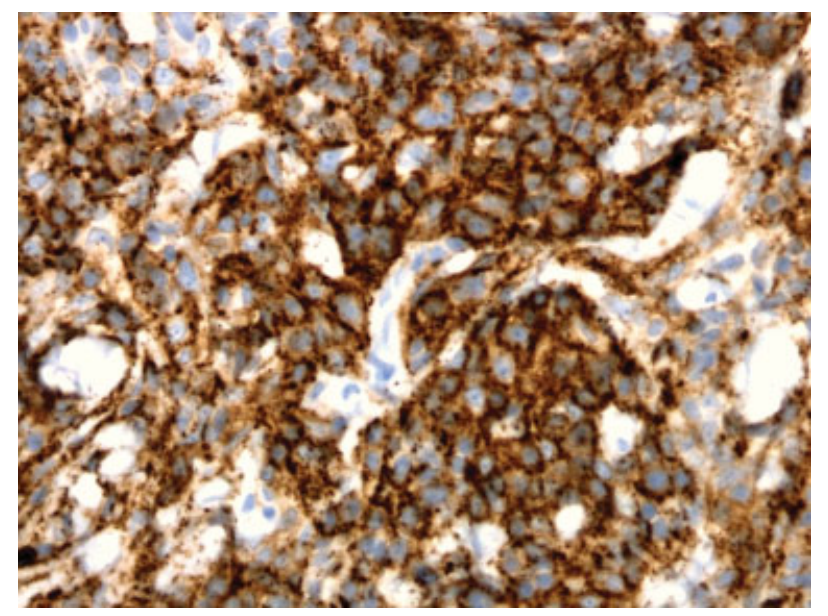

Fig. 4 Large cells are CD20 positive, indicative of B-cell lineage $(\times 400)$. 
Table 1 Diffuse large B-cell lymphoma cases found in the literature

\begin{tabular}{|c|c|c|c|c|c|c|c|}
\hline Study & Pathology & $\begin{array}{l}\text { Age, yl } \\
\text { Sex }\end{array}$ & Presenting signs & Type of report & Stage & Treatment & Prognosis \\
\hline Duncavage et $\mathrm{al}^{13}$ & NA & NA & Facial swelling & Case series & IVE & NA & NA \\
\hline Burres et $\mathrm{al}^{4}$ & DLBCL & $43 / F$ & $\begin{array}{l}\text { Frontal headache, } \\
\text { nasal drainage }\end{array}$ & Case report & $\mathrm{IE}$ & $\begin{array}{l}\text { Chemotherapy, } \\
\text { surgery }\end{array}$ & $\begin{array}{l}\text { NED at } \\
2 \text { mo }\end{array}$ \\
\hline Frierson et al ${ }^{16}$ & NA & NA & NA & Case series & NA & NA & NA \\
\hline $\begin{array}{l}\text { Cooper and } \\
\text { Ginsberg }^{17}\end{array}$ & DLBCL & $60 / F$ & $\begin{array}{l}\text { Enlarging nodule on } \\
\text { nose }\end{array}$ & Case series & $\mathrm{IE}$ & $\begin{array}{l}\text { Chemotherapy, } \\
\text { radiotherapy }\end{array}$ & $\begin{array}{l}\text { NED at } \\
20 \text { mo }\end{array}$ \\
\hline Spiro et al ${ }^{15}$ & NA & NA & NA & Case series & NA & NA & NA \\
\hline el-Hakim et al ${ }^{5}$ & DLBCL & $58 / \mathrm{M}$ & $\begin{array}{l}\text { Eyelid edema, fron- } \\
\text { tal headaches, epi- } \\
\text { staxis, nasal } \\
\text { obstruction }\end{array}$ & Case report & $\mathrm{IE}$ & $\begin{array}{l}\text { Chemotherapy, } \\
\text { sinus surgery }\end{array}$ & $\begin{array}{l}\text { NED at } \\
3 \text { mo }\end{array}$ \\
\hline Hatta et $a^{14}$ & NA & NA & NA & Case series & NA & NA & NA \\
\hline Shohat et al $^{12}$ & DLBCL & $83 / \mathrm{M}$ & $\begin{array}{l}\text { Pain, nasal dis- } \\
\text { charge, headache, } \\
\text { nasal bleeding }\end{array}$ & Case series & IIIE & $\begin{array}{l}\text { Chemotherapy, } \\
\text { radiotherapy }\end{array}$ & NA \\
\hline Neves et $\mathrm{al}^{6}$ & DLBCL & $43 / \mathrm{M}$ & $\begin{array}{l}\text { Frontal headaches, } \\
\text { bulging eyelid }\end{array}$ & Case report & NA & NA & DOD; NA \\
\hline Nemet et $\mathrm{al}^{7}$ & DLBCL & $84 / \mathrm{M}$ & $\begin{array}{l}\text { Nontender periorbi- } \\
\text { tal swelling }\end{array}$ & Case report & $\mathrm{IE}$ & $\begin{array}{l}\text { Steroids, } \\
\text { radiotherapy }\end{array}$ & $\begin{array}{l}\text { DOD at } \\
9 \text { mo }\end{array}$ \\
\hline $\begin{array}{l}\text { Chain and } \\
\text { Kingdom }^{8}\end{array}$ & DLBCL & $55 / \mathrm{M}$ & $\begin{array}{l}\text { Pain and swelling of } \\
\text { forehead }\end{array}$ & Case report & IIEA & $\begin{array}{l}\text { Chemotherapy, } \\
\text { radiotherapy }\end{array}$ & $\begin{array}{l}\text { NED at } \\
18 \mathrm{mo}\end{array}$ \\
\hline Kim et $\mathrm{al}^{9}$ & DLBCL & $42 / \mathrm{M}$ & $\begin{array}{l}\text { Multiple cranial } \\
\text { nerve palsies }\end{array}$ & Case report & IVE & $\begin{array}{l}\text { Chemotherapy, } \\
\text { stem cell therapy }\end{array}$ & $\begin{array}{l}\text { NED at } \\
50 \text { mo }\end{array}$ \\
\hline Wong et al ${ }^{10}$ & DLBCL & $61 / \mathrm{F}$ & Enlarging forehead & Case report & NA & Chemotherapy & NA \\
\hline Philip et al ${ }^{11}$ & NA & NA & NA & Case report & NA & NA & NA \\
\hline $\begin{array}{l}\text { Arnautović } \\
\text { et al (this report) }\end{array}$ & DLBCL & $53 / \mathrm{M}$ & $\begin{array}{l}\text { Headaches, dizzi- } \\
\text { ness, eye tender- } \\
\text { ness, nasal } \\
\text { congestion }\end{array}$ & Case report & $\mathrm{IE}$ & $\begin{array}{l}\text { Surgery, } \\
\text { chemotherapy }\end{array}$ & $\begin{array}{l}\text { NED at } \\
12 \text { mo }\end{array}$ \\
\hline
\end{tabular}

Abbreviations: DLBCL, diffuse large B-cell lymphoma; DOD, died of disease; NA, not available; NED, no evidence of disease. Source: Table modified from Kim et al. ${ }^{9}$

radiation therapy in various combinations. Lymphoma is a pathology that is both chemosensitive and radiosensitive. Surgery can be performed to establish a diagnosis offering both an oncologic and often a neurologic benefit to the patient. Our case used a combination of surgery and chemotherapy to provide symptom-free disease control.

Previously reported presentations of frontal sinus NHL were a direct result of tumor mass effect and not presented as a chronic infection. The lack of specificity of symptoms related to this disease unfortunately often leads to a delayed diagnosis. The diagnosis of sinonasal lymphoma may remain elusive for months to years leading to delays in treatment. The experience in our case is that even intraoperatively an infection was presumed. It was only after negative swab cultures and positive histology that a diagnosis of NHL was made. Therefore, an attempt at an endoscopic biopsy of "granulation tissue" for histologic examination should be considered before subjecting a patient to surgical treatment in suspected cases.
It is our hope that this report will increase awareness of this disease for physicians to obtain earlier diagnosis, more timely treatments, and, most importantly, improved outcomes for patients.

\section{Conclusion}

Sinonasal NHL is rare but can occur in the frontal sinus. Most of the symptoms are tumor nonspecific. It can present as Pott puffy tumor and may be easily overlooked at surgery unless histologic specimens are submitted and reviewed in detail. A high clinical suspicion is necessary for early diagnosis and treatment. Prior to surgery, endoscopic biopsy should be considered in suspected cases.

\section{Disclosures}

The authors have no financial relationships to disclose. No funding was accepted for this study. 


\section{Acknowledgments}

We would like to thank Andrew J. Gienapp for technical and copy editing, preparation of the manuscript and figures for publishing, and publication assistance with this manuscript. Immunoglobulin gene rearrangement assays by multiplex polymerase chain reaction/capillary electrophoresis were performed at Molecular Pathology Laboratory Network, Maryville, Tennessee.

\section{References}

1 Howlader N, Noone AM, Krapcho M, et al , eds. SEER Cancer Statistics Review, 1975-2010. National Cancer Institute Web site. http://seer.cancer.gov/csr/1975_2010/

2 Cleary KR, Batsakis JG. Sinonasal lymphomas. Ann Otol Rhinol Laryngol 1994;103(11):911-914

3 Fellbaum C, Hansmann ML, Lennert K. Malignant lymphomas of the nasal cavity and paranasal sinuses. Virchows Arch A Pathol Anat Histopathol 1989;414(5):399-405

4 Burres SA, Crissman JD, McKenna J, Al-Sarraf M. Lymphoma of the frontal sinus. Case report and review of literature. Arch Otolaryngol 1984;110(4):270-273

5 el-Hakim H, Ahsan F, Wills LC. Primary non-Hodgkin's lymphoma of the frontal sinus: how we diagnosed it. Ear Nose Throat J 2000; 79(9):738, 741-743

6 Neves MC, Lessa MM, Voegels RL, Butugan O. Primary nonHodgkin's lymphoma of the frontal sinus: case report and review of the literature. Ear Nose Throat J 2005;84(1):47-51

7 Nemet AY, Deckel Y, Kourt G. Orbital invasion of frontal sinus lymphoma. Orbit 2006;25(2):149-151

8 Chain JRK, Kingdom TT. Non-Hodgkin's lymphoma of the frontal sinus presenting as osteomyelitis. Am J Otolaryngol 2007;28(1):42-45

9 Kim K, Kim MJ, Ahn S, Bae SY, Kim WS, Yoon JH. Frontal sinus lymphoma presenting as progressive multiple cranial nerve palsy. Yonsei Med J 2011;52(6):1044-1047

10 Wong EH, Yang WY, Lowe D. Unilateral non-Hodgkin's lymphoma of the frontal sinus presenting as Pott's puffy tumour. Otolaryngol Pol 2013;67(4):214-217
11 Philip JK, Al-Jassar A, Naquib IS, Usmani S, El-Kabani M, Refaat SM. Primary Non-Hodgkin lymphoma of frontal sinus diagnosed by fine needle aspiration cytology. Gulf J Oncolog 2013;1(13): 92-95

12 Shohat I, Berkowicz M, Dori S, et al. Primary non-Hodgkin's lymphoma of the sinonasal tract. Oral Surg Oral Med Oral Pathol Oral Radiol Endod 2004;97(3):328-331

13 Duncavage JA, Campbell BH, Hanson GA, et al. Diagnosis of malignant lymphomas of the nasal cavity, paranasal sinuses and nasopharynx. Laryngoscope 1983;93(10):1276-1280

14 Hatta C, Ogasawara H, Okita J, Kubota A, Ishida M, Sakagami M. Non-Hodgkin's malignant lymphoma of the sinonasal tract-treatment outcome for 53 patients according to REAL classification. Auris Nasus Larynx 2001;28(1):55-60

15 Spiro JD, Soo KC, Spiro RH. Nonsquamous cell malignant neoplasms of the nasal cavities and paranasal sinuses. Head Neck 1995;17(2):114-118

16 Frierson HF Jr, Mills SE, Innes DJ Jr. Non-Hodgkin's lymphomas of the sinonasal region: histologic subtypes and their clinicopathologic features. Am J Clin Pathol 1984;81(6):721-727

17 Cooper DL, Ginsberg SS. Brief chemotherapy, involved field radiation therapy, and central nervous system prophylaxis for paranasal sinus lymphoma. Cancer 1992;69(12):2888-2893

18 Hans CP, Weisenburger DD, Greiner TC, et al. Confirmation of the molecular classification of diffuse large B-cell lymphoma by immunohistochemistry using a tissue microarray. Blood 2004; 103(1):275-282

19 Vidal RW, Devaney K, Ferlito A, Rinaldo A, Carbone A. Sinonasal malignant lymphomas: a distinct clinicopathological category. Ann Otol Rhinol Laryngol 1999;108(4):411-419

20 Quraishi MS, Bessell EM, Clark D, Jones NS, Bradley PJ. NonHodgkin's lymphoma of the sinonasal tract. Laryngoscope 2000; 110(9):1489-1492

21 Logsdon MD, Ha CS, Kavadi VS, Cabanillas F, Hess MA, Cox JD. Lymphoma of the nasal cavity and paranasal sinuses: improved outcome and altered prognostic factors with combined modality therapy. Cancer 1997;80(3):477-488

22 Banooni P, Rickman LS, Ward DM. Pott puffy tumor associated with intranasal methamphetamine. JAMA 2000;283(10):1293 